\title{
PELATIHAN PENGENALAN LEGISLATIVE DRAFTING UNTUK PEMBENTUKAN PERATURAN DESA BAGI APARATUR DESA CIGUGURGIRANG KECAMATAN PARONGPONG KABUPATEN BANDUNG BARAT
}

\author{
Sumiyati $^{1}$, Ita Susanti, Hazma ${ }^{1}$, Wastukurning Purbandini ${ }^{1}$, M. Syamsul Hidayat ${ }^{1}$ \\ ${ }^{1}$ UP-MKU,Politeknik Negeri Bandung \\ Email: sumiyati@polban.ac.id, aaty shanty@yahoo.co.id, hz umma@yahoo.com, \\ wastupurbandini262@gmail.com, syam35.hd@gmail.com
}

\begin{abstract}
Abstrak
Kepala Desa bersama Badan Permusyawaratan Desa menetapkan Peraturan Desa setelah dibahas dan sisepakati bersama. Dalam penyelenggaraan Pemerintahan dan Pembangunan Desa, peraturan tersebut merupakan kerangka hukum dan kebijakan yang berlaku. Peraturan Desa yang dibentuk atau ditetapkan dalam Peraturan Perundang-undangan ini memuat norma hukum dan mengikat secara umum. Legislasi merupakan pembentukan peraturan dapat menjadi pilihan oleh pembuatnya untuk menyajikan kebijakan dengan cara yang sangat kuat dalam menciptakan suatu keadaan. Legislasi juga dapat menjadi pilihan untuk menyajikan kebijakan dengan menciptakan suatu dinamika hukum masyarakat. Oleh karena itu, kemampuan para aparatur desa dalam menyusun peraturan desa perlu ditingkatkan agar apa yang menjadi tujuan sebuah desa untuk memberdayakan seluruh sumber daya yang ada agar demokratis, mandiri, kuat, dan maju dapat terwujud. Kegiatan pengabdian kepada masyarakat ini dilakukan dengan menggandeng mitra aparatur Desa Cigugurgirang, terutama anggota Badan Permusyawaratan Desa (BPD), melalui kegiatan Pelatihan Pengenalan Legislative Drafting untuk Pembentukan Peraturan Desa Bagi Aparatur Desa Cigugurgirang. Luaran kegiatan ini berupa jasa atau aktivitas pelatihan updating Ipteks di masyarakat dan peningkatan kegiatan pengembangan ilmu, teknologi, dan seni di perguruan tinggi, serta untuk Polban kegiatan ini diharapkan dapat memperkenalkan Polban sebagai institusi pendidikan vokasi yang berdomisili di Kabupaten Bandung Barat.
\end{abstract}

Kata kunci: Legislative drafting, pelatihan, aparatur desa

\section{PENDAHULUAN}

Di seluruh Indonesia, desa memiliki karakteristik yang berlaku umum. Karakteristik tersebut berupa hak tradisional dan hak asal usul yang berguna bagi kepentingan warganya dalam mengurus dan mengatur desa. Dengan hak tersebut, akan tercipta desa yang maju, kuat, mandiri dan demokratis yang turut andil 
DIFUSI

Volume 2, No.2 Juli 2019

dalam pelaksanaan pembangunan mengisi kemerdekaan menuju masyarakat yang adil, makmur dan sejahtera berdasarkan UUD 1945 [1].

Penyelenggaraan pemerintahan desa perlu akuntabilitas mengingat kedudukan, kewenangan, dan keuangan desa semakin kuat. Penyelenggaraan ini perlu didukung oleh sistem pengawasan dan keseimbangan antara pemerintah dan lembaga desa. BPD sebagai badan permusyawaratan mempunyai fungsi penting dalam menyiapkan kebijakan Pemerintahan Desa. BPD bersama kepala desa harus mempunyai visi dan misi yang sama sehingga BPD tidak dapat menjatuhkan kepala desa yang dipilih secara demokratis oleh masyarakat desa.

BPD merupakan suatu lembaga yang melaksanakan tugas pemerintahan yang anggotanya terdiri dari wakil penduduk Desa yang ditetapkan secara demokratis berdasarkan keterwakilan wilayah. Sebagai badan permusyawaratan, lembaga ini mempunyai peran membahas dan menyepakati berbagai kebijakan dalam penyelenggaraan Pemerintahan desa, juga memperkuat kebersamaan, serta meningkatkan pemberdayaan dan partisipasi masyarakat dalam upaya meningkatkan kinerja kelembagaan di tingkat Desa. Pemerintah Desa dan/atau BPD memfasilitasi penyelenggaraan Musyawarah Desa. Musyawarah Desa merupakan forum musyawarah antara BPD, Pemerintah Desa, dan unsur masyarakat yang untuk memusyawarahkan dan menyepakati hal yang bersifat strategis dalam penyelenggaraan Pemerintahan Desa. Bentuk kesepakatan dari hasil Musyawarah Desa dituangkan dalam keputusan hasil musyawarah dan dijadikan dasar dalam menetapkan kebijakan Pemerintahan Desa.

Peraturan Desa adalah penjabaran atas berbagai kewenangan yang dimiliki desa serta mengacu pada ketentuan peraturan perundang-undangan yang lebih tinggi. Peraturan Desa, sebagai sebuah produk hukum, tidak boleh bertentangan dengan peraturan yang lebih tinggi dan tidak boleh merugikan kepentingan $\mathrm{u}$ mum. Hal yang dimaksud tersebut adalah

1. kerukunan antarwarga masyarakat; terganggu;

2. akses terhadap pelayanan publik terganggu

3. ketenteraman dan ketertiban umum terganggu;

4. kegiatan ekonomi untuk meningkatkan kesejahteraan masyarakat Desa terganggu; dan

5. kepercayaan dan ras, suku, agama, antargolongan, serta gender terdiskriminasi.

Sebagai sebuah produk politik, Peraturan Desa diproses dengan mengikutsertakan partisipasi masyarakat Desa yang berhak untuk mengusulkan atau memberikan masukan kepada Kepala Desa dan BPD dalam proses penyusunan Peraturan Desa.

Sebagaimana dikatakan oleh Wahyu (2013), bahwa sebagai negara hukum partisipasi masyarakat untuk mengawasi dalam penyusunan undang-undang di setiap sidangnya pada tahapan legislatif. Apalagi, sebagai negara deliberasi komunikasi, menuntut para wakil rakyat di parlemen untuk berdialog, berkomunikasi dengan rakyatnya untuk bahan 
DIFUSI

Volume 2, No.2 Juli 2019

pertimbangan dalam keputusan pembuatan hukum, guna mencapai suatu konsesi bersama.

Peraturan Desa pelaksanaannya diawasi oleh masyarakat Desa dan BPD. Tujuannya agar pelaksanaan Peraturan Desa dapat diawasi oleh warga masyarakat Desa setempat karena Peraturan Desa ditetapkan untuk kepentingan masyarakat Desa. Peraturan Desa sebagai produk peraturan perundang-undangan merupakan peraturan tertulis yang memuat norma hukum yang mengikat secara umum dan dibentuk atau ditetapkan dalam Peraturan Perundangundangan. Legislasi merupakan pembentukan peraturan yang dapat menjadi pilihan untuk menyajikan kebijakan dengan cara yang sangat kuat dalam menciptakan suatu keadaan. Legislasi juga dapat menjadi pilihan pembuatnya untuk menyajikan kebijakan dengan menciptakan suatu dinamika hukum masyarakat (Khaleed, 2014).

Berdasarkan UU No. 12 Tahun 2011 diatur mengenai Pembentukan Peraturan Perundang-undangan yang mencakup tahapan perencanaan, penyusunan, pembahasan, pengesahan atau penetapan, dan pengundangan. Oleh karena itu, kemampuan para aparatur desa dalam menyusun peraturan desa perlu ditingkatkan, agar apa yang menjadi tujuan sebuah desa untuk memberdayakan seluruh sumber daya yang ada dapat terwujud.

\section{METODE}

Kegiatan yang dilakukan berbentuk pelatihan, didahului dengan penyampaian teori dilanjutkan dengan praktik. Pela- tihan direncanakan akan berlangsung selama 44 jam. Adapun jumlah peserta diperkirakan sekitar 20-25 orang anggota BPD Desa Cigugurgirang.

Untuk mempertegas rencana kegiatan, secara garis besar digambarkan dalam diagram alir berikut ini:

1. Pada tahap awal, diadakan tes kemampuan awal (pre-test) dan hasilnya diidentifikasi dan dievaluasi untuk mengetahui kondisi pemahaman awal peserta dengan diberikan pertanyaan berupa angket yang berisi materi pelatihan legislative drafting tingkat dasar.

2. Tahap berikutnya disampaikan materi legislative drafting secara teori dengan metode ceramah. Pada tahap ini, disampaikan teori pendukung berkaitan dengan hal-hal yang akan dilatihkan.

3. Penyampaian materi legislative drafting secara praktik. Pada tahap ini, peserta praktik secara mandiri atau berkelompok untuk berlatih merancang pembentukan peraturan desa di bawah bimbingan narasumber.

4. Latihan implementasi dan pendalaman materi legislative drafting. Pada tahap ini dilakukan metode tanya jawab. Hal ini sangat penting bagi para peserta pelatihan, baik di saat menerima penjelasan tentang manfaat legislative drafting serta bagaimana mempraktikkannya. Metode ini memungkinkan para peserta menggali pengetahuan sebanyakbanyaknya tentang manfaat legislative drafting dalam pembentukan peraturan desa serta bagaimana pengalaman setelah praktik me- 
manfaatkan legislative drafting dalam pembentukan peraturan desa.

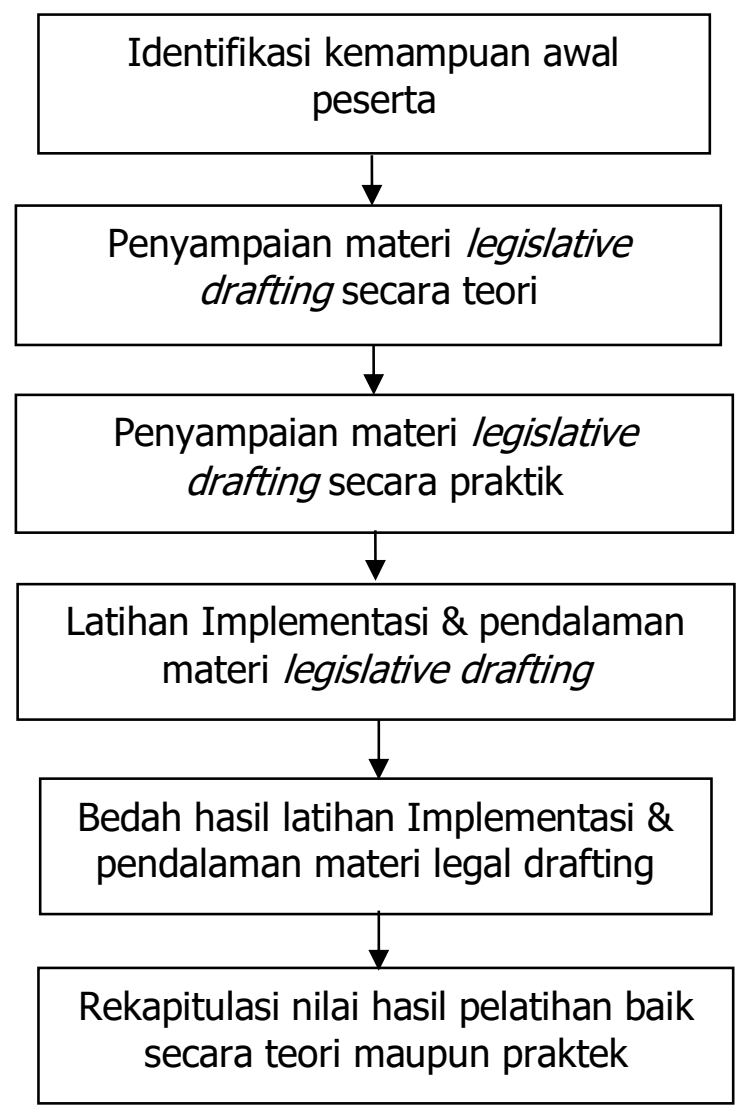

Gambar 1. Bagan alir

5. Bedah hasil latihan implementasi dan pendalaman materi legislative drafting. Pada tahap ini dilakukan metode simulasi; metode ini sangat penting bagi peserta pelatihan untuk memperoleh kesempatan mempraktikan materi pelatihan yang diperoleh secara teknis dan mengidentifikasi kesulitan-kesulitan (jika ada) untuk kemudian dipecahkan.

6. Rekapitulasi nilai hasil pelatihan baik secara teori maupun praktik. Pada tahap ini para peserta diberi tugas mandiri sebagai implementasi legislative drafting secara lebih spesifik berdasarkan kebutuhan pe- serta. Selanjutnya para peserta dievaluasi melalui post-test, untuk mengukur bagaimana hasil pelatihan legislative drafting yang telah diberikan.

7. Evaluasi hasil pelatihan keseluruhan sebagai evaluasi akhir dilakukan setelah seluruh rangkaian kegiatan pelatihan selesai dilakukan.

8. Untuk melihat keberhasilan pelaksanaan kegiatan secara keseluruhan perlu diadakan evaluasi.

\section{HASIL DAN PEMBAHASAN}

Kegiatan yang dilaksanakan pada tanggal 24 Oktober 2016 bertempat di Ruang Serba Guna Desa Cigugurgirang Kecamatan Parongpong Kabupaten Bandung Barat semula dijadwalkan akan diikuti oleh 25 orang peserta pelatihan yang berasal dari unsur BPD dan Perangkat Desa. Namun, pada akhirnya kegiatan pelatihan diikuti oleh 28 orang dengan tiga orang peserta tambahan yang berasal dari tokoh masyarakat desa.

Selain itu, pelatihan yang semula diarahkan pada keterampilan Legal Drafting/Legislative Drafting (tata cara penyusunan/pembuatan peraturan) bagi anggota BPD Desa Cigugur Girang, berubah menjadi pelatihan/workshop Pengenalan Legal Drafting/Legislative Drafting (tata cara penyusunan/pembuatan peraturan) bagi Aparatur Desa Cigugur Girang. Hal ini dilakukan setelah mendengarkan pendapat dan masukan dari aparatur Desa, terutama Sekretaris Desa dan Ketua serta Anggota BPD Desa Cigugur Girang, yang menjelaskan bahwa akan terlalu berat jika langsung diberikan pelatihan 
DIFUSI

Volume 2, No.2 Juli 2019

pembuatan/penyusunan peraturan perundang-undangan, sementara pengetahuan tentang hal tersebut sama sekali belum pernah didapatkan. Selain itu, latar belakang peserta yang beragam dan kebanyakan petani kurang memungkinkan untuk langsung menerima pelatihan pembuatan/penyusunan peraturan perundang-undangan.

Secara terinci pelaksanaan pelatihan Legal Drafting/Legislative Drafting ditinjau dari aspek materi, aspek sarana dan prasarana, serta aspek peserta dapat diuraikan sebagai berikut:

\section{a. Aspek Materi:}

1) Pemilihan materi disesuaikan dengan kebutuhan peserta pelatihan sekaligus dijadikan sebagai media sosialisasi peraturan-peraturan terkait pemerintahan desa yang terbaru, seperti UU Desa yang baru efektif berlaku per tanggal 1 Januari 2015.

2) Peserta pelatihan dibekali seperangkat alat tulis dan handout materi pelatihan dan dibagi menjadi beberapa kelompok dengan nama kelompok yang berbeda-beda bertemakan nama kepulauan maupun provinsi yang ada di Indonesia yang dipilih dan alasan pemilihan nama kelompok serta mewajibkan setiap kelompok untuk memiliki yel-yel sebagai penyemangat peserta selama mengikuti pelatihan.

3) Penyampaian materi terbagi kedalam tiga sesi, yang diakhiri dengan kuis maupun simulasi kelompok pada setiap sesinya. Agar tidak membosankan dan dapat disajikan lebih menarik, penyam- paian materi dilakukan secara dialogis juga dengan menayangkan tayangan yang relevan serta pemberian hadiah sebagai wujud apresiasi tim kepada peserta pelatihan yang mampu menjawab pertanyakan yang sengaja tim siapkan, kelompok dengan yel-yel terbaik dan kelompok yang paling kompak dan bagus rancangan serta analisis melakukan drafting peraturan desa.

4) Setelah materi pelatihan disampaikan dilakukan simulasi kepada peserta pelatihan dengan mencoba menganalisa sejumlah peraturan desa yang telah berlaku dan ada sebelumnya, terutama dari perspektif hukum serta penulisan dan pemilihan kata menurut Bahasa Indonesia yang baik dan benar.

5) Sebagai tugas terakhir pelatihan, masing-masing kelompok diwajibkan menyusun draft contoh peraturan desa yang kelompok pandang perlu diadakan pengaturannya secara garis besar.

\section{b. Aspek Sarana dan Prasarana:}

Sarana dan fasilitas pelatihan cukup menunjang suasana pelatihan sehingga peserta mampu memahami materi yang disampaikan nara sumber dengan baik. Hal tersebut terlihat dengan setiap pemberian tugas dan pertanyaan dari tim dapat diselesaikan dengan baik oleh peserta pelatihan atau masing-masing kelompok. Antusiasme peserta pelatihan juga sangat nampak pada saat setiap kelompok harus melakukan presentasi tugas akhirnya yang berupa penyampaian gagasan, ide tentang draft peraturan desa 
DIFUSI

Volume 2, No.2 Juli 2019

secara garis besar yang dirasa perlu segera diadakan pengaturannya.

\section{c. Aspek Peserta:}

1) Para peserta merasa sangat terbantu dengan materi pelatihan legislative drafting yang diberikan tim pengabdian, terutama seperti apa yang diwakili dan disampaikan Kepala Desa dan Ketua BPD Cigugurgirang kepada tim sehingga mereka ingin mulai memberanikan diri melakukan analisis dan menyusun peraturan desanya sendiri dengan cara hendak meninggalkan kebiasaan lama mereka yang melakukan copy paste dari peraturan desa lain.

2) Para peserta, mengharapkan akan ada pelatihan lanjutan terkait legislative drafting yang mereka ikut saat ini, dengan waktu, tempat dan sarana yang jauh lebih baik sehingga diharapkan desa memiliki drafter peraturan perundang-undangan desa yang dapat diandalkan, baik mewakili Badan Permusyawaratan Desa maupun dari kalangan Aparatur Desa (Perangkat Desa).

3) Pemahaman peserta pelatihan tentang pentingnya pemahaman penyusunan peraturan desa atau hal lain yang berkaitan dengan penyelenggaraan desa menjadi jauh lebih baik, dan peserta pelatihan sebagai mitra berharap bahwa kerja sama yang dilakukannya dengan tim akan terus berlanjut pada bidang lainnya di masa yang akan datang.

\section{KESIMPULAN}

Berdasarkan kegiatan pengabdian kepada masyarakat yang tim lakukan dalam bentuk pelatihan penyusunan draft peraturan desa, maka beberapa hal yang menjadi kesimpulan kami yaitu:

1. Pemahaman peserta pelatihan yang terdiri atas unsur Perangkat Desa (executive) dan BPD (legislative) sebagai pembentuk peraturan desa meningkat.

2. Keterampilan Perangkat Desa (executive) maupun BPD (legislative) dalam menyusun draft peraturan desanya sendiri meningkat.

\section{REFERENSI}

[1] Undang-Undang Nomor 6 Tahun 2014 Tentang Desa, Lembaran Negara Republik Indonesia Nomor 7 Tahun 2014.

[2] Badriyah Khaleed, 2014, Legislatif Drafting, Teori dan Praktik Penyusunan Peraturan Perundangundangan, Penerbit Pustaka Yustisia, Yogyakarta, Cetakan Pertama.

[3] Bagir Manan, 2007, Material Course Hukum Perundang-Undangan, Fakultas Hukum, Universitas Gajah Mada, Yogyakarta.

[4] Maria Farida S Indrati, 2007, Ilmu Perundang-Undangan:Proses dan Teknik Pembentukannya (Buku 2), Penerbit Kanisius, Yogyakarta.

[5] Nugroho Wahyu, Menyususn Undang-Undang yang Responsif dan Pertisipatif Berdasarkan Cita Hukum Pancasila, Jurnal LEGISLASI INDONESIA, Vol. 10 No.3- September 2013. 
DIFUSI

Volume 2, No.2 Juli 2019

[6] Peraturan Pemerintah Nomor 43 Tahun 2014 Tentang Pelaksanaan

Undang-Undang Nomor 6 Tahun 2014 Tentang Desa. 